\title{
Advancing Racial Equality through Insights from Canadian Indigenous Art and Literature
}

\author{
Carol A. Mullen \\ Virginia Tech, USA
}

\begin{abstract}
The purpose of this qualitative study is to explore the promise of racial equality through insights from Canadian indigenous art and literature. Research and creative artistry are connected in this discussion to policy, education, and ecosystems. Researchers of indigeneity advance perspectives on colonization and accountability to decolonizing all aspects of aboriginal life within geopolitical contexts. Methods used were a targeted literature review of indigenous writings and an analysis of Canadian indigenous art productions. 'An overarching idea establishes indigenous voice as truth telling about, and tribal protest of, colonialism as a problem of humanity. Dismantling colonial systems is an activist goal.
\end{abstract}

\section{Introduction}

This preliminary qualitative study addresses the indigenous call in contemporary Canadian indigenous art and literature for decolonizing education, ecosystems, healthcare, and all systems including the judicial system. Being recognized in these sources is the status of indigenous peoples as an invisibilized or minoritized community for whom dominant narratives and theories have been used against them. The hope is to restory knowledge, research, and curriculum to advance their sovereignty and wellbeing. This research explores indigenous critical scholarship and creative artistry, connecting to policy, education, and curriculum. Of interest are indigenous views of accountability to colonization within geopolitical contexts, particularly Canada's global cultural context. Value for dismantling colonial educational environments, worldwide, is under study. Implications for leading, teaching, and learning are pursued as an ongoing project.

\section{Theoretical Framework}

Minoritized refers to the perpetual state of being exploited and dehumanized as an underrepresented group. Lowman and Barker [7] add that confronting White settler mentality is an indigenous commitment to change. Denial of colonial legacy and responsibility as an ongoing problem is a "hot button" in the Canadian indigenous art and literature analyzed. Being called out is a lack of accountability by colonial settler states for unjust treatment and betrayal of indigenous communities and for hiding behind "systems of power"-economic and educational inequality, racism, and "political marginalization" (Lowman \& Barker). Activists see majoritarian populations and structures as complicit in systems of dispossession that displace indigenous communities. Just as "cultural dispossession and assimilation are central to colonization" [10], repossession of land as a tribal right and entitlement drives decolonization [16].

Land dispossession occurs daily for indigenous peoples forced to uproot and assimilate [19]. Canada's claim of land sovereignty is met with indigenous creative resistance and protest, without reparations for stolen native lands and resources [16], [20]. With the stark imbalance in power, indigenous assertions of land rights result in denial, even punishment. Impoverished education, inadequate healthcare and housing, and imprisonment are tools enforcing colonialism. Unsafe and contaminated environments; overrepresentation of suicides, homicides, and missing and murdered females; eviction, poor nutrition, and illness; prejudice, bias, and abuse; and lack of opportunity, unemployment, and underemployment are but some sources of distress that indigenous communities endure. To expound, indigenous families endure polluted water supplies and land eviction, often leading to homelessness [7]. "Material differences" are evident by those "most impacted by unjust social practices" [5]. Tribal justice targets the return of stolen homeland without penalties that include domination and abandonment, state Lowman and Barker.

Indigenous children and youth have the right to experience schooling attuned to them and their cultures. Quite possibly, this stance constitutes the moral spine of indigenous writing in education [5], [20]. While gravely under-researched, school leadership greatly matters to the change process. Keddie and Niesche [6] studied a White principal's leadership of a rural indigenous school in Australia. 
The leader's relationship with "indigenity" proved culturally lacking (reductionist) and her worldview irreconcilable with indigenous life. By normalizing White hegemony, she was perpetuating the colonizing and oppressive spaces of schooling at the expense of indigenous voice, success, and empowerment.

Education, like health, is a fundamental human right. The UN [18] has named poverty, conflict, healthcare, and education in its endorsement of indigenous communities' rights. Yet, North America's record of justice on behalf of its indigenous peoples is appalling: "Indigenous peoples living in the richest countries of the United States and Canada are among their poorest citizens" (p. 7). Widespread exclusionary schooling of indigenous communities is still common. Roughly, $70 \%$ of First Nations students drop out of high school. About 19\% of Canada's federal prisoners are indigenous but represent only $3 \%$ of the total population [17].

Confronting bankrupt indigenous education, tribal nations resist "continued colonial acts" in schooling [20]. Scholars from this ethnic group report ways to assist White practitioners with discovering and forging pathways that utilize inclusive community strategies. These include infusing "tribally based values into public and tribal school curriculum" and developing "student-centered education" to expand work/life options [20]. Decolonization efforts as such "propose a shift in educational philosophy to student as citizen and centered in community" (Writer, p. 173). Culturally attuned curricula reflect worldviews and values endemic to indigenous paradigms (e.g., tribal identity and kinship structures). Cultural programming must astutely incorporate both indigenous and Western knowledge and values and meet expectations of school systems in which indigenous communities engage in partnerships between home and school [5]. A goal is for indigenous learners to become biculturally literate and adaptive, a strategy for coping with disengagement, failure, and dropout and for having prospects for success in life.

Beyond educational injustice is colonial violation of the environment and indigenous communities' ecosystems. Analysis of systems reveals that Canada is but one colonial oppressor practicing White European domination and settler tactics, including genocidal campaigns [19]. "Cultural genocide" in modern-day forms includes the "ecological devastation of indigenous territories"; North American "colonial expansion" is equated with genocide and ongoing "multiple and coordinated efforts to destroy [aboriginal] unique forms of group life" [19].

In present time northern Alberta, Canada, for example, genocide's ecological dimensions continue to threaten the very existence of First Nations communities. The Tar Sands Gigaproject's oil extraction produces toxic waste that flow into water systems, resulting in rare cancers endangering many natives' lives [4]. Another contemporary example of genocidal effects owing to colonial legacy involves the "child welfare (dis)placements" of Indigenous children and youth who "die in care" through homicide, suicide, and so forth at more significant rates than their non-indigenous counterparts [9]. As typifies genocidal campaigns, Navia et al. charge, the Canadian citizenry is complicit in the "ongoing forms of settler colonialism experienced in child welfare systems today" (p. 146), making that much more dangerous the racist systems ironically designed to protect and educate native children who are overrepresented in systems of care.

Critical aspects of Inuit education include "environmental knowledge, experiential learning, caring between teacher and learner, and family control over child-rearing" [8]. From this perspective, support services and social entities (e.g., healthcare providers, churches) typically invisible in Eurocentric institutions have a vital educative role to play in the quality of aboriginal students' lives. This need is evidenced by a growing number of interventionist studies and programs, many of which exist in the margins outside formal delivery systems in an effort to combat chronic disease and terminal illness that is disproportionately high in indigenous populations [20]. Building on this sensibility, while healthcare awareness and intervention is essential to Indigenous students' quality of life and educational success, support systems, religious entities, and so forth within North America have been failing to educate aboriginal communities with integrity and for success [3], [12]. In fact, as indigenous activists assert, all of us are "complicit in settlement, making us all settlers, [but] not all settlers are created equal" [13].

\section{Methods}

As a scholar hosted in Toronto in 2017, my research questions were: (1) "How does critical scholarship and Canadian indigenous creative artistry within public spaces inform global trends and forces of accountability for Canada?" and (2) "What are implications of indigenous agency for education, policy, and leadership?" Methods used were a targeted literature review of indigenous writings and an analysis of Canadian indigenous art productions.

\subsection{Literature and searches}

Analyzed was the contemporary literature (2004 to 2018) on accountability relative to indigenous issues, especially in Canada. Public discourse from Canadian governmental sources and media was searched. Peerreviewed studies and public documents were obtained via library databases with expansive holdings of indigenous sources. Search terms included accountability, Canada, colonization, decolonization, education, global, indigenous, policy, and school. 


\subsection{Research site and location}

The Art Gallery of Ontario's [1] exhibition was the main research site. Toronto locations were visited over a month. As a White person, my blind spots reflect my socialization within a colonial framework. Non-native visitors on tribal lands are "guests" [20], so I imagined the exhibits as sacred territories and approached with respectful accord. In my U.S. educational leadership program, I teach aspiring leaders using cultural lenses.

\subsection{Data collection and analysis}

After collecting data, I recorded my notes via speech-recognition software. Moving the recordings to my laptop generated verbatim transcriptions. I also analyzed my photographs of the artwork and artists' posted descriptions. NVivo 11® software helped manage the transcriptions. Search terms (keywords) were organizers of this data. A qualitative document analysis [14] of the transcriptions was performed. A frequency count of keywords identified emergent themes. Another qualitative researcher's review confirmed interrater reliability. Stage and Manning affirmed an exploratory approach to analysis because "visual artifacts" are the most "under-utilized technique" in research. Lending credibility to my treatment, I chose which artwork to highlight using my first research question. The same professor reviewed my 200 selections for pre-analysis. We chose six creations reflecting the politics of water and land, featuring two.

\section{Discussion-Based Findings}

\subsection{Literature}

Conceptual frames, derived from scholarship, were organized around the ideas presented of colonialism as tribal injustice. An overarching idea establishes indigenous voice as political truth telling about, and tribal protest of, colonialism.

\subsection{Artworks}

The AGO's "Reframing Nationhood" exhibition was approached as a space for exercising the public imagination. "Not all narratives begin in 1867" was the venue's greeting. In 2017, the nation was celebrating its 150th birthday, but the artistry conveyed an old world inhabited by indigenous peoples for millennia before Europeans arrived. Ironically, while Canada was undergoing identity transformation [11], it held onto the falsehood of its origins. With the 1867 proclamation of its birth, the nation cloaked its historical legacy, which the artistry challenged.
Politics of water was one major theme emerging from the analysis. Inscribed on the AGO's exhibit floor was this entreaty, "In this vast space, who has access to clean water, land, and housing?" For example, Cuthand's caption for 94 baby bottles with colorful glass beads was Don't Breathe, Don't Drink. Being signified were bacteria, viruses, or parasites in contaminated water. Being "shown" was an epidemic of national proportions for Canada's indigenous people. Water contamination, a serious health issue, had overtaken 94 of the country's First Nation communities. With the widespread disasters involving water, indigenous peoples have been pushed "to formulate innovative and powerful responses to the contamination, exploitation, and theft of water, even as they are silenced by genocidal schemes" [15]. Communities end up devastated, which is why indigenous declarations of water-related emergencies continue. Widespread environmental disasters indeed exist. Adverse health effects for fetuses and babies result from polluted baby bottles. Tainted water sources are associated with alarming medical complications that can result from exposure to dangerous chemicals.

A remote northern Ontario reservation, Attawapiskat First Nation has suffered numerous water crises. For example, residents "lack access to running water and electricity," despite being located on a waterway; a "severe housing shortage" compounds this problem [2]. Tensions with the federal government escalated when Indigenous residents were questioned over why they had called a state of emergency. An administrative liaison retorted that they had already received "millions," implying liability and blame. The same news story cited more such emergencies called by this reserve. "Flooding and sewer backups" in 2013 caused snow-collapsed infrastructure: "The rising sewage forced [a hospital's] evacuation."

Another more dominant theme was the politics of land. "Whose home on native land?" was inscribed on the gallery floor. These works evoked land politics. For example, Magnussen's sculpture, Man Has Reached Out and Touched the Tranquil Moon, animates the colonial desire to possess land and take ownership, extending to the moon. The moon-land analogy brings into view the corporatization of land and conversion into government (or corporate) owned assets. With sole proprietorship as the impetus, power is wielded. Land can connote estate/property (settler worldview) or place/home (indigenous worldview). Colonial possession involves taking the home of another and controlling its occupants and resources. Magnussen's use of "own" three times in his description of the artwork animates the dynamic of possession, in effect stimulating the colonial settler mindset (of the viewer) to think and possibly act.

Paradoxically, the moon-a "new world"-is described as "tranquil" by the artist. As a world 
society, we have been lulled into believing the first space mission was peaceful; in actuality, the Western settler compulsion was to compete for ownership of the moon and exploit its habitat by harnessing resources. The moon-land analogy brings into view the corporatization of land and conversion into government (or corporate) owned assets. With sole proprietorship as the impetus, power over others is wielded; ethics of responsibility, relationship, and reciprocity-defining touchstones in Indigenous culture - are not values in colonial nations.

The environmental metaphor of land dispossession in indigenous lives was a takeaway for this visitor to the AGO exhibition, just as was water toxicity on Canadian indigenous reserves. Together, the AGO art installations serve as a window onto an aesthetics of crisis expressed as toxic (baby) bottles and stolen lands. These are prevailing themes of the artwork and analysis. Because the land and water themes in select art productions as well as publications voice modernday universal concerns in Indigenous culture, these political images are centerpieces of this article.

Invoking a politics of liability, all of the AGO artworks conveyed environmental injustice through land possession and colonial devastation of ecosystems. The power of communal vision was part of this aesthetic of political outreach and solidarity. Being interrogated was settler colonialization of indigenous peoples, the conduit of which was art.

\section{Conclusions}

How might educators and school leaders subvert a settler futurity in the protection and support of aboriginal populations made vulnerable by colonist ambition? In response, this ensemble of indigenous scholars and artists teaches that the subjugating of indigenous communities is an ongoing crisis of humanity. The aim for schools in decolonizing and even indigenizing education is honest, responsible work in racial relations. A concern involves settlers' motives to decolonize paradigms and schooling where self-servingly designed to "reconcile guilt" and "rescue settler futurity" [16]. But, developing fluency with indigenous viewpoints is a starting point, understanding that political inequality is at the root of the White-indigenous relationship.

Finally, tribal justice is a pursuit of racial equality that disrupts colonial inertia and propels re-seeing accountability in light of wrongdoing. Indigenous activists call for dismantling systems of colonization and revisiting social justice paradigms that bypass colonialism and tribal justice. It must be remembered that much work lies ahead in bringing about racial, political, educational, and social equality as "postcolonialism is an ideal not yet achieved" [10].

\section{References}

[1] Art Gallery of Ontario (AGO). (2017). AGO this week [brochure]. Toronto, ON: Author.

[2] Canadian Press, The. (2016). States of emergency Attawapiskat has declared in recent years. Retrieved from http://www.cbc.ca/news/canada/sudbury/Attawapisk at-states-of-emergency-1.3530222. (Access Date: 25 May, 2018).

[3] Hare, J., \& Pidgeon, M. (2011). The way of the warrior: Indigenous youth navigating the challenges of schooling. Canadian Journal of Education, 34(2), 93-111.

[4] Huseman, J., \& Short, D. (2012). "A slow industrial genocide": Tar sands and the indigenous peoples of northern Alberta. International Journal of Human Rights, 16(1), 216-237.

[5] Johnson, G., \& Dempster, N. (2014). Challenging dominant discourses of home-school partnerships in indigenous communities. In I. Bogotch \& C. Shields (Eds.), International handbook of educational leadership and social [in]justice (vol. 1; pp. 397-421). New York, NY: Springer.

[6] Keddie, A., \& Niesche, R. (2012). "It's almost like a White school now": Racialised complexities, Indigenous representation and school leadership. Critical Studies in Education, 53(2), 169-182.

[7] Lowman, E. B., \& Barker, A. J. (2015). Settler: Identity and colonialism in 21 st century Canada. Black Point, NS: Fernwood Publishing.

[8] McGregor, H. E. (2013). Situating Nunavut education with Indigenous education in Canada. Canadian Journal of Education, 36(2), 87-118.

[9] Navia, D., Henderson, R. I., \& Charger, L. F. (2018). Uncovering colonial legacies: Voices of Indigenous youth on child welfare (dis)placements. Anthropology \& Education Quarterly, 49(2), 146-164.

[10] Pinto, L. E., \& Blue, L. E. (2015). Pushing the entrepreneurial prodigy: Canadian Aboriginal entrepreneurship education initiatives. Critical Studies in Education, 1-18.

[11] Politics of Canada. (2017). Wikipedia. Retrieved from https://en.wikipedia.org/wiki/ Politics_of_Canada. (Access Date: 5 May, 2018).

[12] Royal Commission on Aboriginal Peoples, The. (1996). Report of the Royal Commission on Aboriginal Peoples. [Five volume set]. Ottawa, ON: Canada Communication Group. Retrieved from https://www.baclac.gc.ca/eng/discover/aboriginal-heritage/royalcommission-aboriginal-peoples/ Pages/final-report.aspx. (Access Date: 1 May, 2018).

[13] Snelgrove, C., Dhamoon, R. K., \& Corntassel, J. (2014). Unsettling settler colonialism: The discourse and politics of settlers, and solidarity with Indigenous nations. 
Decolonization: Indigeneity, Education \& Society, 3(2), 132.

[14] Stage, F. K., \& Manning, K. (Eds.). (2016). Research in the college context: Approaches and methods (2nd ed.). New York, NY: Routledge.

[15] Tabar, L., \& Desai, C. (2016). Special issue: Indigenous peoples and the politics of water [call for papers.] Retrieved from http://www.decolonization. org/index.php/des/announcement/view/511. (Access Date: 18 May, 2018).

[16] Tuck, E., \& Yang, K. W. (2012). Decolonization is not a metaphor. Decolonization: Indigeneity, Education \& Society, 1(1), 1-40.

[17] United Nations (UN). (2010). State of the world's indigenous peoples: Press release. Retrieved from https://www.un.org/esa/socdev/unpfii/ documents/SOWIP/ press\%20package/sowip-press-package-en.pdf. (Access Date: 18 April, 2018).

[18] United Nations (UN). (2016). State of the world's indigenous peoples. Retrieved from http://www.un.org/esa/socdev/unpfii/documents/

2016/Docs-updates/The-State-of-The-Worlds-IndigenousPeoples-2-WEB.pdf. (Access Date: 2 April, 2018).

[19] Woolford, A., \& Benvenuto, J. (2015). Canada and colonial genocide. Journal of Genocide Research, 17(4), 373-390.

[20] Writer, J. H. (2017). Sustaining the essence: Community values, knowledges, and ways of being. Kappa Delta Pi Record, 53(4), 168-173. 